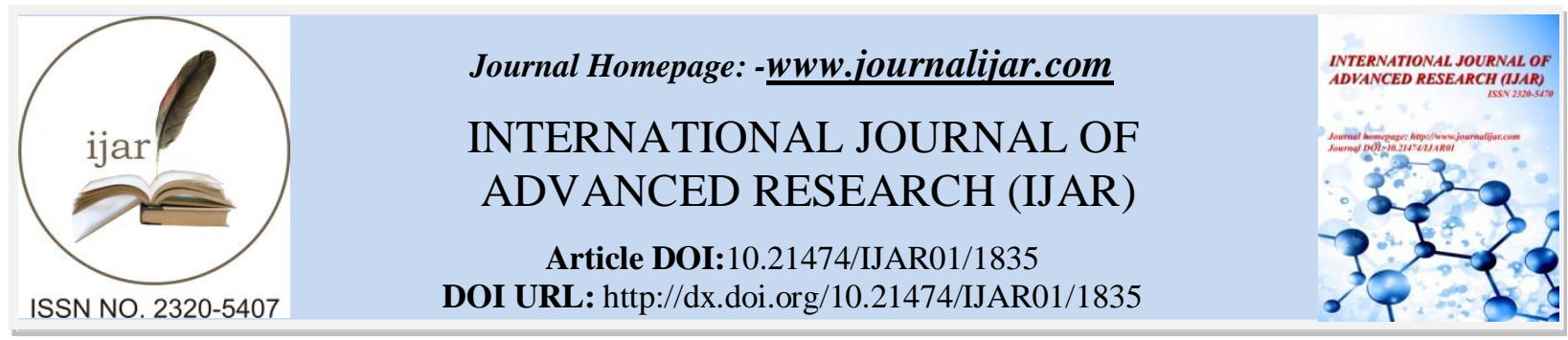

RESEARCH ARTICLE

\title{
CHARACTERISTICS OF THE ISRAEL'S SOCIALISTIC ECONOMY.
}

\author{
Daniel Galily ${ }^{1}$ and David Schwartz ${ }^{2}$. \\ 1. Dean of student's affairs, Los Angeles University, United States. \\ 2. Political Science department, Bar-Ilan University, Israel.
}

\section{Manuscript Info}

Manuscript History

Received: 12 August 2016

Final Accepted: 23 September 2016

Published: October 2016

\section{Abstract}

From the early Jewish settlements, there was a collectivist social opinion that encourages the subordination of personal needs in favor of collective needsfor the building of a new Jewish State.

Copy Right, IJAR, 2016,. All rights reserved.

When Jewish settlements began to be established in the Land of Israel in large numbers, with the goal of building a future State, at the end of the $19^{\text {th }}$ century and at the beginning of the $20^{\text {th }}$ century, most of the immigrants and the political leaders were from the Soviet countries in Eastern Europe. Consequently, a collectivist social opinion began to form that encourages the subordination of personal needs in favor of collective needs for the building and development of a new Jewish State ${ }^{1}$.

\section{Economic Aspects in the Collective Identity:-}

The economic content world of the collective identity includes fundamental traits of the economic action, which are related, directly or indirectly, to the Zionist ideology and the ideological goals in light of which Jewish society in the Land of Israel developed, and to constraints dictated by the reality in the Land of Israel. Therefore, the discussion of the economic content world of the Zionist collective identity should begin with the presentation of the three characteristics that accompanied the Zionist economic activity for a long period of time.

First, this activity was dictated by the national goals, and the good of the nation was the supreme consideration. Second, the economic feasibility of this activity was most slight. Third, this activity was connected in a close and multifaceted manner to politics. Indeed, many researchers will agree with the statement that the main trait of the economic sector in Israel from its first days was its considerable subordination to the national-political imperatives and to the organizations and institutions that represented these imperatives, namely the parties and the pan-national institutions.

This combination of characteristics created tension between economic considerations that derived from the market imperatives and its conditions and political considerations that derived from the aspiration to realize the national ideology. This tension was the fundamental problem of the economy of the Jewish community in the Land of Israel and of the State of Israel for many years, and it is apparent in a number of dimensions of economic activity ${ }^{2}$.

\section{The Tension between the Market Imperatives and the National Imperatives:-}

\footnotetext{
${ }^{1}$ Smith, B. J. (Ed.) (1993). The Roots of Separatism in Palestine: British Economic Policy, 1920-1929.

${ }^{2}$ Yaar, E., \& Shavit, Z. (Eds.). (2001). Trends in Israeli Society (Vol. 1). Tel Aviv: Open University of Israel. (Hebrew).
} 
Most of the Zionist goals had economic implications, whether direct or indirect. One economic implication of the goal to establish a new Jewish society in the Land of Israel, which would be different from the Jewish society in the Diaspora, was the social-economic 'rehabilitation' of the Jews: the establishment of a productive occupational structure that means the referral of most of the immigrants to manual labor and the manufacturing of products with economic worth.

A second implication was the construction of a modern economic sector, from the foundations, since in the Ottoman Land of Israel there barely was an infrastructure for modern economic activity. The technical and administrative infrastructure was largely built by the British Mandate government, according to the Mandate given to Britain. However, the Jewish settlers strived to establish a productive economy and a system of services, and in this, too, they had to begin from the foundations, since the economy of the old Jewish community was primarily based on support from the outside and there was very little independent productive activity, and in any event the new arrivals sought to disconnect themselves from the old community ${ }^{3}$.

The economic significance of the Jewish settlement in the Land of Israel was the extensive investments in the purchase and preparation of lands, in the construction of infrastructures for the communities (building homes, planting orchards, etc.), and support of the communities until they developed a productive economy of their own. The immigration of Jews to the Land of Israel also had economic significance, and primarily for the investment in the absorption of the immigrants who came without their own capital: assurance of occupation and housing, professional training, so as to integrate the immigrants in the productive economic activity, and different services including those that constitute processes for the socialization of the immigrant, for example language instruction. However, in the period that preceded the establishment of the State of Israel immigrants with capital also came and could finance their absorption, but the lack of appropriate central planning prevented the intelligent use of this capital and induced crises.

Most of this economic activity was not profitable, since the investments led to national-political benefit but not financial profit. In the preface to his book on the economic side of the realization of the Zionist ideology, Kimmerling ${ }^{4}$ notes three examples of the lack of economic worthwhileness. One significant example is the issue of the purchase of land. As Kimmerling shows elsewhere, in the years 1910-1944 the prices of land in Israel soared and were extremely high, and moreover, the moment lands were transferred to Jewish hands, they became national lands and could not be sold. The tremendous investment in the purchase of land therefore had political benefit but no economic profit.

Another example is the cost of labor. Most of the immigrants came without any training for productive work but the primary available work in the first decades of the Zionist enterprise was manual labor - in agriculture, in the preparation of infrastructures, or in craftsmanship. However, many of the immigrants aspired to engage in productive work out of purely ideological motives but their output was low and it remained that way for a considerableperiod of time, until they acquired training and experience.

In contrast, the standard of living to which they were accustomed in their countries of origin was high in comparison to the standard of living of the simple workers in the Land of Israel in this period. Therefore, they demanded a relatively high wage. The available solution for employers was to turn to cheap Arab labor, but this solution was not commensurate with the national ideolog $y^{5}$.

\footnotetext{
${ }^{3}$ Plessner, Y. (1994). The Political Economy of Israel: From Ideology to Stagnation, p.72. Google Books. Retrieved on September 8. 2011.

${ }^{4}$ Kimmerling, B. (2001). The End of the Ashkenazi Hegemony. Jerusalem: Keter Press. (Hebrew)

${ }^{5}$ Mark, C. (2004). "Israel: US Foreign Assistance", Congressional Research Service, July 12, 2004.

Retrieved July19, 2012.
} 
The issue of the Jewish labor was a topic of severe struggles. Moreover, the meaning of immigration in this context was the incessant entry of workers who were inexperienced and who therefore were expensive in the employers' opinion, into the job market.

In other words, the Zionist objective itself - to encourage as much immigration as possible, at a pace and scope not necessarily dictated by economic considerations - influenced the economic situation. Therefore, the question of the economic regulation of the immigration arose: to create a balance between the contribution of the immigration in terms of the human capital and the need for the investments of economic capital that would facilitate the absorption of the human capital and the production of benefit from it. A third example of the economic weakpoint of the realization of the Zionist ideologies is the question of the investments in defense and security, created as a result of the national conflict on the Jewish settlement in the Land of Israel.

These investments were intended to establish, arm, and train military organizations, and from the capital invested directly in defense it is possible to note on the loss side the expense of the workforce from the productive work circle. The investments in security steadily increased over the years, without there being any profit. In essence, such a profit was produced only with the development of the arms industry in the State of Israel. Since the choice of the regions of settlement were also influenced by the national and security considerations, according to the availability of the lands for settlement in the period of the British Mandate, settlements were founded in distant regions, without any economic justification for their establishment.

The tension between the national imperatives and the economic imperatives originated, therefore, in the placement of the economic activity in the service of the ideological objectives. The economic activity, which by nature was supposed to be held in the economic markets according to considerations of cost-benefit and supply-demand, was subordinated to ideological imperatives that did not take into account economic needs, under conditions that were definitely not financial ${ }^{6}$.

Kimmerling ${ }^{7}$ maintains that the ideological solution to this tension was given through the development of a pioneering ethos that emphasized the sacrifice of the individual for the good of the collective and for a better future. The economic activity that was guided by the national imperatives was therefore 'pioneering economics'.

Already in 1927, Haim Orlozorov defined this type of economic activity as 'heroic economics', economics in which the economic institution does not act for purely profit goals but undertakes the burden of the construction of the national home. In essence, Orlozorov intended to define a new type of economic adventure and criticized the economic activity of the Histadrut (the Workers Union) in the first half of the 1920s.

Since then the Histadrut changed some of its ways of economic activity, although not radically. For many years, even after the establishment of the State, the national-ideological imperatives continued to dictate the economic ways of actions, for instance, the opening of the country to unrestricted immigration and the assignment of the responsibility to the State to absorb the immigrants. Last, the pioneering ethos had an additional implication, which originates in the norms of 'making do with a little'. These norms dictated a simple life style and the avoidance of conspicuous consumption, even when the individuals had the means for this ${ }^{8}$.

\section{The Struggle between Socialism and Capitalism in the EconomicActivity in Israel:-}

The recognition of the national importance of an economy was shared by all the components of the political spectrum in the Jewish settlement in the Land of Israel and the argument about it revolved around the question of the appropriate way of developing it. The main outlooks in this argument were the socialist outlook and the capitalistliberal outlook, although the camps that held these outlooks were not uniform.

The socialist outlook was represented by the Labor Movement, when the main parties in it were HaPoelHaTsair (the Young Worker), which was not avowedly socialist, and AchdutHaAvoda (Unity of Work), which over the years

\footnotetext{
${ }^{6}$ Fischer, S. (1987). "The Israeli Stabilization Program, 1985-86". The American Economic Review. American Economic Association. 77 (2)

${ }^{7}$ Kimmerling, B. (1993). Theory and Criticism of Militarism in Israeli Society, Fall, pp. 4, 123-140.

${ }^{8}$ Yaar, E., \& Shavit, Z. (Eds.). (2001). Trends in Israeli Society (Vol. 1). Tel Aviv: Open University of Israel. (in Hebrew) (Eds.)
} 
became more moderate in the socialist enthusiasm that characterized it at its beginning. The question of the extent to which the Israeli Labor Movement was a socialist movement is at the center of the dispute among the researchers of the history of Israeli society. Some maintain that the Labor Movement stopped being socialist already in an early stage of its existence.

However, the economic regime that formed when its leaders were the leaders of the Jewish community in the land of Israel was very centralized. While this centralization was a relic of the socialistic perception of economic-political management, this trait of the Israeli economy indicated the desire to accumulate power, more than ideological adherence.

Others hold that the Labor Movement remained socialist to some degree or another, but along with the socialist paradigm it adopted the national paradigm. The contemporary rhetoric indicates without a doubt that the heads of the movement and its activists were convinced that their outlooks and deeds were socialist outlooks and deeds. However, research studies show that the Labor Movement failed in its attempts to implement socialist principles such as equality, class solidarity, and social justice'.

The liberal capitalist outlook was represented by three political camps - the general Zionists, the Mizrachi movement, and the Revisionist movement. The 'standard bearer' of this outlook was the general Zionist camp, which saw it to be the main component in its ideology. This political camp represented most of the private entrepreneurs and capital owners in the Jewish community.

In the framework of the discussions on the ideological attitudes of the general Zionists there are two approaches, one conservative and one liberal. The conservative approach adopted uncompromising capitalist attitudes, while the liberal approach adopted more moderate capitalist attitudes, which recognized the national need for centralized leadership of the Zionist economy and cooperation with the middle class and the labor movement. For the Mizrachi movement and the Revisionist movement, the capitalist outlook was a component in the ideology but not the main one. However, in the framework of the political rivalry between it and the labor movement, the Revisionist movement emphasized its position for a free economy and against worker struggles and strikes.

Therefore, in the ideological and rhetorical dimension socialism and capitalism existed as two different and even rivalling social-economic outlooks. The political power was in the hands of the Labor Movement, which saw itself as having socialist outlooks and as having a large part of the economic activity in its hands, but the economic power was primarily in the hands of private entrepreneurs who held the liberal capitalist outlook. However, in both sides there were factors that necessarily recognized the need to cooperate so as to achieve the national goals and therefore recognize the legitimacy of the two outlooks and the inability to force on the Jewish community a comprehensive and inclusive social-economic outlook of any type.

Thus, two sectors of economic activity existed side by side - the public sector, operated by the Labor Movement, as the dominant political organization in the Jewish community, and the private sector. Each one of the sectors held its own outlook regarding the ideal model of economic activity, but in actuality the private entrepreneurs, who had the economic power, agreed to the centralized management of the community economy by the political leadership while the Labor Movement, with the political power, agreed to the existence of private initiative and a free economy market outside of its own sector. The model of economic activity in the Jewish community was not a socialist or capitalist model, but a mixed model, and the faithful expression of this model was the dual sectorial structure of the

\section{Import of Capital:-} economy ${ }^{10}$.

When the products of the communities of the First Immigration to the Land of Israel are examined in the terms of this discussion, it is possible to say that the economic and financial hardships are related largely to the attempt to realize national goals through economic activity that makes use of private capital and relies on considerations of economic feasibility, without taking into account the tension between the market imperatives and the national imperatives. While in its first years the Zionist movement did not form an unequivocal position on economic questions, immediately with the establishment of the World Zionist Organization it began an institutional effort to

\footnotetext{
${ }^{9}$ Bank of Israel (2012). "Israel's International Investment Position (IIP), June 2012". September 19, 2012. Retrieved October 15, 2012.

${ }^{10}$ Yaar, E., \& Shavit, Z. (Eds.). (2001). Trends in Israeli Society (Vol. 1). Tel Aviv: Open University of Israel. (in Hebrew)
} 
recruit capital from worldwide Jewry. This capital, which was consideredthe capital of the national movement, was used to finance the achievement of the national goals, alongside the private capital ${ }^{11}$.

There is a distinction between national capital, which was recruited using the organizations of the World Zionist Organization, primarily the Jewish National Fund (JNF, or in Hebrew Keren KayemetLeYisrael, KKL) and the United Israel Appeal (Keren HaYesod), as well as organizations like Hadassah, WIZO, and Aid Fund for the Land of Israel, and public capital, which was recruited through non-Zionist organizations, primarily PICA (Palestine Jewish Colonization Association), the Joint, and KAPAI (Hebrew acronym for the Fund for the Workers of the Land of Israel). However, in the summative presentation of the data of the capital, they are addressedgenerally as one unit - national and public capital. In the period of the Ottoman government and the British military government, there was the allocation of the entire national capital and of some of the public capital by the Israeli Land Office and then by the Zionist Executive in Jerusalem and then by the management of the Jewish Agency, which was established primarily to recruit funds from Jews around the world. The allocation of public capital was undertaken by political organizations that recruited this capital, for instance, the Labor Movement, which commanded KAPAI.

The private capital was brought by immigrants with capital, and the Mandate government even encouraged their coming so as to increase the investments in the economic development of the Land of Israel. The rate of private capital brought in the period of the pre-State settlement of the Land of Israel was always considerable larger than the rate of the public-national capital ${ }^{12}$.

\section{The Dual Structure of the Economy - Private Capital and Public Capital:-}

The division of the capital that was brought to the Land of Israel into public-national capital and private capital created the structural division of the economy of the Jewish society to the public-national ${ }^{13}$ sector and to the private sector $^{14}$. These two sectors are different not only in size - as aforementioned, the private sector was always considerably larger than the public-national sector - but also in the directions of their activity, the economic perceptions that characterized them, and in the degree of political power that each one relied upon, since the private sector did not succeed in translating its economic power into political power. These two sectors existed side by side and recognized the importance of the other sector, primarily after the Labor Movement became the dominant political organization in the national institutions at the beginning of the 1930s.

The division into the two sectors exists today as well, but it has experienced changes. After the establishment of the State of Israel, the country became owners of a large part of the sector. First, the State appropriated the lands of Arabs who had fled or been expelled during the War of Independence, the lands of the Mandate government, and the lands of the JNF. Second, with the establishment of a mechanism of bureaucratic control the State became the largest employer.

In the first decades after the establishment of the State, the public-national sector greatly increased. However, afterwards public property was sold only to the private sector. The import of capital remained a main characteristic of the Israeli economy, although the dominance of one-sided capital from global Jewry ${ }^{15}$ was replaced by the dominance of two-sided capital from other countries and international organizations, through the State, and private investors.

The division into two sectors expresses not only the two types of ownership of capital and property but also two separate perceptions of economic activity. The Zionist movement held the pluralistic perception in all that pertains to economic activity, but one of the implications of the argument between Weizmann and Brandeis was the preference of the national and public capital and the centralized management of the economic activity since the private capital was less subordinate than the public national capital to the good of the nation. Even when the private capital was directed to investments commensurate with the national interests, the use of it was dictated first and

\footnotetext{
${ }^{11}$ Benchimol, J. (2016). "Money and Monetary Policy in Israel during the Last Decade". Journal of Policy Modeling 38 (1): 103-124.

${ }^{12}$ Yaar, E., \& Shavit, Z. (Eds.). (2001). Trends in Israeli Society (Vol. 1). Tel Aviv: Open University of Israel. (in Hebrew)

${ }^{13}$ In essence comes from donations and thus is a one-sided import.

${ }^{14}$ Comes from investments and thus is two-way import.

${ }^{15}$ Through the State and the Jewish Agency
} 
foremost by considerations of profit and loss, as opposed to the public and national capital, for which the considerations in the investment were secondary. The political dominance of the Labor Movement tilted the scales even further in favor of the public national capital and the centralized perception. This perception dominated the management of Israel economy for many years and its structural implications are still manifest today ${ }^{16}$.

\section{Politicization of the Economic Activity:-}

The roots of the politicization of the economic activity can be found in two factors. The first is the main role of the Zionist Executive and the management of the Jewish Agency in the allocation of the capital recruited from the Jews around the world and in the allocation of the immigration permits. The second is the entry of parties into economic activity. As aforementioned, the management of the economy by the national movement was a lesson learned following the economic hardships of the communities of the First Immigration and the necessity to enforce 'national logic' on the economic activity, to achieved national-economic goals. However, the Zionist Executive and the Jewish Agency management were political organizations whose members represented the political-ideological groups in Zionism and saw their status, as responsible for the allocation of economic resources, as a position of political power.

Thus, there was an opening not only for the dominance of national considerations over the economic activity but also for the development of the power struggles and for the transformation of the recruitment and allocation of financial resources into a mechanism of the implementation of authority by the national institutions as a partial substitute for the absence of sovereignty. The economic activity became a field of struggle between the politicalideological groups and the between them and the national institutions.

In this struggle, the Labor Movement had advantages from the beginning, in comparison to the other groups, since the parties of the Labor Movement began their activity already in the first decade of the 20th century and were better organized than every other political-ideological in the community. Because of the circumstances of their appearance they fit into a wide variety of areas of activity, including economic activity, and established an elaborate institutional structure, the significant expression of which was the mechanism of the Histadrut. Because of this institutional structure, the parties of the Labor Movement could absorb new members and ensure their loyalty. In addition, their leaders were possessed of political awareness, initiative, and drive and could control and direct the party members.

Therefore, the institutions of the Labor Movement could act considerably in the economic field, for the achievement of the national goals. Moreover, the parties of the Labor Movement were perceived by themselves and by others prominent in the Zionist Movement leadership ${ }^{17}$ as a primary power that could realize the national goals and therefore as deserving of support. In contrast to these parties, the political and organizational weakness of the organizations of the political center and the right's excessive focus on the political on the political dimension were very prominent.

The preferred position of the Labor Movement was expressed in the respectable segment of the public-national capital and immigration licenses that it received, and these enabled it to develop its own economic sector and to influence the development of the economy of the entire Jewish community. The desire to obtain resources from the Zionist Executive led eventually the parties of the Labor Movement to focus their efforts on achieving a majority in the Zionist Executive. Their victory in the elections to the management of the World Zionist Organization and to the management of the Jewish Agency in the first half of the 1930s established the position of their hegemony not only in the field of the determination of the political stances of the Jewish settlement, but also in all that pertained to the allocation of the economic resources.From this time onward, the Labor Movement became the organization in the Jewish community in the land of Israel that most influenced the establishment of a centralized and collectivist economic policy ${ }^{18}$.

As aforementioned, the second factor of the politicization of the economy of the Jewish settlement was the economic activity of the parties of the Labor Movement. The roots of this activity should be sought in the period of the growth of these parties and in the tradition of the political culture influencing them. At first the parties of the

\footnotetext{
${ }^{16}$ Yaar, E., \& Shavit, Z. (Eds.). (2001). Trends in Israeli Society (Vol. 1). Tel Aviv: Open University of Israel. (in Hebrew)

${ }^{17}$ Such as Arthur Rupin and Haim Weizmann.

${ }^{18}$ Melnick, R., \&Mealemen, Y. (2009). Israel's Economy: 1986-2008, June 2009.
} 
Labor Movement and the non-party worker organizations supplied the material lacks of their members, and then the economic activity of the Youth Movement was formed in the framework of the Histadrut, through the development of existing economic institutions ${ }^{19}$ and through the establishment of other economic institutions ${ }^{20}$.

All these institutions were collected in the framework of the Workers' Company and over the years this became an economic giant. The extensive economic activity of the Histadrutwas integrated in political activity and served as an instrument for the accumulation of political power, both in the period of pre-statehood settlement and in the period of the country ${ }^{21}$.

The mix of politics and economics in the Workers' Companyis presented as follows. It should be emphasized that one of the goals for the establishment of a company of workers was from the beginning to support the Histadrut economically and politically. In the Workers' Company politics and economics were always been combined.

The politicization and 'nationalization' of the economic activity has most important significance in the economic content world of the collective identity, since they can explain the considerable degree of intervention of the government in the State of Israel in the economic activity. In the Israel economy the public-national sector was constructed on a far larger scale than the private sector, so as to absorb immigration. However, consequently, the political weakness of the supporters of the private market caused the situation in which they were forced to accept the dictates of the State's centralized economy, which saw the construction of the State economy to be the main issue and not the laws of the free economy such as supply and demand.

\section{Conclusion:-}

To conclude, the transition from settlement to State, which occurred without political and structural shocks, allowed the situation that reigned in the settlement economy to be copied to the state economy, although the economic roles of the national institutions were transferred to the government of Israel, and the power relations that exist between the centralized-national economic perception and the perception of the free market and non-government intervention to be preserved.

The source of the tradition of intervention lies also in the socialist influence on the LaborMovement. The economic activity of the Labor Movement tended clearly to centralized planning and supervision, for instance, in the issue of the equalization of the salary or in questions of employment policy. Another expression of the socialist influence can be seen in the very use of economic power, for example the power built in the framework of a workers' company, so as to fortify political interests and political hegemony ${ }^{22}$.

\footnotetext{
${ }^{19}$ Company for Public Works and the Mashbir.

${ }^{20}$ HaPoalim Bank, HaSneh Insurance Company, Tnuva, KupatCholim (a healthcare system), cooperatives for production and services, factories and industrial plants, Funds for the recruitment of money, loans, and credit. ${ }^{21}$ The collectivist ideology of the heads of the Labor Movement is what dictated the establishment and management of economic organizations by the political organization and the control of the economic resources enabled them to make their movement the dominant one in the Jewish community in the Land of Israel.

${ }^{22}$ Yaar, E., \& Shavit, Z. (Eds.). (2001). Trends in Israeli Society (Vol. 1). Tel Aviv: Open University of Israel. (in Hebrew) (Eds.)
} 